\title{
“'ONDE ESTÁ O MENINO JESUS?" NATÁLIA CORREIA VISITA ALBERTO CAEIRO
}

Marcelo Sandmann*

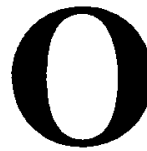

universo ficcional pessoano desgarrou-se de seu genial demiurgo. Modeladas no barro fértil da sua linguagem de grande poeta, animadas pelo vigor do seu sopro criador, suas máscaras saltaram do rosto, abandonaram os limites nada exíguos dos textos escritos pelo próprio Pessoa e vieram povoar a narrativa portuguesa recente.

Amadeu Lopes Sabino põe em cena os encontros de Álvaro de Campos com seu reverenciado mestre Alberto Caeiro. Ao longo do conto "O Lepidóptero" (O retrato de Rubens - 1985), os dois famosos heterônimos discutem poesia e política na Lisboa modernista e republicana de 1915.

José Saramago, num romance fundamental ( $O$ ano da morte de Ricardo Reis - 1984), centra o foco ficcional neste outro heterônimo. Regressando do seu auto-exílio brasileiro em fins de 1935, logo após a morte de Fernando Pessoa, Ricardo Reis vê posto em xeque o seu papel de sábio e distanciado observador do espetáculo do mundo. No bojo de um Portugal já plenamente salazarista e de uma Europa dilacerada por radicalizações políticas que estão a gestar a próxima grande guerra, confrontando afetiva e ideologicamente com outras personagens - historicizado e humanizado, portanto -, Reis torna-se objeto de uma labiríntica investigação de identidade.

* Universidade Federal do Paraná. 
E Natália correia, no seu "Onde está o menino Jesus?" (conto publicado em 1985 em antologia de vários autores e textos inéditos), partindo diferentemente não da transformação dos heterônimos em personagens, mas do aproveitamento ficcional das sugestōes de um texto poético específico - o famoso poema VIII de $O$ guardador de rebanhos, de Alberto Caeiro - revisita de forma saborosamente fantasiosa e irônica um menino Jesus já pessoanamente muito heterodoxo, trazendo-o para dentro do seu próprio universo criativo. É este conto que pretendo estudar aqui, investigando através dele um dos modos possíveis desse curioso e produtivo diálogo da narrativa portuguesa recente com a obra de Pessoa.

Duas epígrafes abrem o conto de Natália, uma de Shri Aurobindo, pensador místico de tradiçāo oriental, e outra de Alberto Caeiro, em versos extraídos do referido poema de $O$ guardador de rebanhos. Ambas põem em foco a natureza de Deus.

Aurobindo pergunta: "Afinal de contas, quem é Deus?" E responde em seguida: "Uma criança eterna, jogando um jogo eterno num eterno jardim." Esta visão do divino e da divindade afasta-se de imediato da visão cristã. Vem-nos à mente Krishna e um dos modos da sua tríplice manifestação: como menino alegre e travesso; como jovem amoroso; como guerreiro e sábio, a proferir as grandes lições do Bagavad Gita. A imagem de Deus como uma criança que joga contrasta com as imagens cristãs: a do Deus patriarcal e virulento do Velho Testamento, por exemplo; ou ainda a do Cristo sacrificado na Cruz, do Novo. A cena da Natividade, com a presença do menino Jesus no colo da mãe ou deitado na manjedoura, adorado pelos reis-magos, pastores e anjos, momento de festa e celebração, tem como seqūência e contraposição a cena da matança dos inocentes e a fuga da Sagrada Familia para o Egito. É sob o signo do sacrifício, portanto, que vem ao mundo o Cristo.

As palavras de Caeiro da segunda epígrafe (não a cito por inteiro) retomam os sentidos da anterior: "Ele é a Eterna Criança, o deus que faltava." Ou ainda: "Ele é o divino que sorri e brinca." O neopaganismo de Caeiro realça uma imagem do divino também em dissonância com a do divino cristão. O poema VIII de $O$ guardador de rebanhos, de onde estes versos vêm, é extenso e profundo. Explicita aspectos fundamentais da personalidade poética e, por extensão, da poesia de Alberto Caeiro. Apresenta motivos e situações retomadas por Natália Correia. Abordá-lo com um pouco mais de cuidado é definir de modo mais preciso o intertex to central do conto em estudo.

Alberto Caeiro, mestre reconhecido dos heterônimos Ricardo Reis e Álvaro de Campos, é poeta bucólico, neopagão, espírito sabiamente resignado frente às realidades do mundo e ao destino do homem - clássico em essência portanto. 
É poeta voltado a uma apreensão objetiva e concreta da realidade, cético diante de noções vagas, abstratas, transcendentes que pretendam compreender o mundo para além da sua superfície mais imediata. Caeiro diz no poema $\mathrm{V}$ de $O$ guardador de rebanhos: "O único sentido íntimo das cousas, / É elas não terem sentido íntimo nenhum."

E nessa direção, é o poeta que vai valorizar os sentidos (e entre eles sobretudo o da visão) como meio ideal de conhecimento da realidade, em detrimento do pensamento: "Pensar é estar doente dos olhos"; "Eu não tenho filosofia: tenho sentidos..." (versos do poema II). E outros ainda, tão fundamentais: "O que nós vemos das cousas são as cousas. / Por que veriamos nós uma cousa se houvesse outra?"; "O essencial é saber ver."; "Mas isso (tristes de nós que trazemos a alma vestida!), / Isso exige um estudo profundo, / Uma aprendizagem de desaprender / (...)" (poema XXIV).

$O$ homem está encharcado de civilização e cultura, tem a "alma vestida", e o véu dessas roupas impede que ele lance sobre o mundo um olhar fresco, virgem, primordial e de essencial conhecimento. $O$ homem pensa excessivamente. É preciso despir a alma. Seguindo os passos do poeta (nestas e em tantas outras passagens), devemos voltar à natureza, pautarmo-nos pelo seu ritmo vital, viver em relativo isolamento, exercitando o olhar no conhecimento claro das coisas. Precisamos resgatar algo de primitivo dentro de nós, algo de puro e essencial que purifique e oriente esse olhar.

E é em relação a essa "aprendizagem" que podemos ler o curiosíssimo poema VIII. Transcrevo versos e sintetizo algumas passagens do texto de Caeiro:

"Num meio-dia de fim de primavera / tive um sonho como uma fotografia. / Vi Jesus Cristo descer à terra. / Veio pela encosta de um monte / Tornado outra vez menino, / A correr e a rolar-se pela erva / $\mathrm{E}$ a arrancar flores para as deitar fora / E a rir de modo a ouvir-se de longe." O menino Jesus fugira do céu, cansado que estava das falsidades e imposturas. Lá tudo era sério demais, irreal e postiço. Tudo em desacordo com a natureza e a simplicidade das coisas do mundo.

O sacrifício na Cruz, a Sagrada Família, a Santíssima Trindade, tudo vai se tornando objeto de aguda irrisão no poema. Verdades cristãs fundamentais são postas em ridículo. Deus é "um velho estúpido e doente", "sempre a escarrar no chão". Nossa Senhora "não era mulher", "era uma mala" em que ele tinha vindo do céu. O Espírito Santo é "uma pomba estúpida", "coça-se com o bico e empoleira-se nas cadeiras e suja-as".

Deus-Filho volta à terra, agora como menino comum ("É uma criança bonita e de riso natural."). Comporta-se devidamente como tal. Sapeca, maroto, traquinas, ele "limpa o nariz ao braço direito", "chapinha nas poças 
de água", "atira pedras aos burros", "corre atrás das raparigas" "e levanta-lhes as saias", etc., etc.

Mora junto com o poeta. Torna-se a princípio seu mestre: "A mim ensinou-me tudo. / Ensinou-me a olhar para as cousas." Mas é algo mais logo a seguir: "E a criança tão humana que é divina / É esta minha cotidiana vida de poeta". O menino habita a alma de Caeiro ("Ele dorme dentro da minha alma"), é o seu modo de compreender o mundo, com tudo o que tem de fresco, virginal, primordial. "Desaprender", no sentido que Caeiro dá ao termo, é em suma adotar essa "puerilidade" fundamental - alegre, lúdica, desprevenida diante do mundo.

Compreendidas as epígrafes e o universo textual de Caeiro ao qual uma delas remete, volto ao conto de Natália Correia para conferir de que modo ele vai se constituir enquanto texto no estreito diálogo com esses outros textos.

Uma narradora em primeira pessoa apresenta-se de imediato e faz alusão direta ao poema de Caeiro: "Senti um grande alívio quando, ao fim destes anos todos, soube onde estava o menino Jesus. Li essa notícia nos versos de um homem que guarda rebanhos com quem ele mora numa casa a meio de um outeiro". Natália parafraseia Caeiro ao descrever os modos traquinas do menino. Porém introduz a seguir a dissonância. A narradora faz restrições à "veracidade" de certa passagem da narrativa poética do heterônimo pessoano - àquela que se refere à fuga do menino Jesus do céu, antes de ir morar com o poeta.

É esse suposto "falseamento da verdade" que serve de pretexto para a nova narrativa. A narradora crê que já não há mais motivos para esconder essa "verdade" ( o que, segundo ela julga, o menino haveria feito com a melhor das intençōes, a fim de não comprometê-la), pois as pessoas envolvidas no episódio já não se encontram ativamente presentes para cobrar qualquer satisfação. Criada a expectativa, inicia-se a narração dos acontecimentos, projetados em direção ao passado, num instante da infância da narradora.

Como se percebe já nos parágrafos introdutórios, o conto vai tirar boa parte da sua força desse jogo de convergências e divergências em relação ao texto de partida. Ele parece oscilar, portanto, entre os pólos antagônicos da paráfrase e da paródia.

E a narradora começa a narrar esse episódio do seu passado de menina. Em linhas gerais, temos o que segue: Numa noite de véspera de Natal, depois de acabados os preparativos para a festa do dia seguinte, a casa envolta em silêncio como que sagrado, a narradora-menina, insone pela expectativa dos presentes que irá receber, ouvindo alguns gemidos insistentes ecoando pela noite, levanta-se da cama e vai averiguar a origem destes. Chega à sala do Presépio, e qual a sua surpresa quando, vinda das palhinhas da manjedoura, 
ouve a voz do Menino Jesus, "um vozeirão" aliás, a interpelá-la de forma diretíssima. Tem a seguir início um insólito e fantástico diálogo entre os dois, pleno de revelações para a menina embasbacada, através do qual o menino Jesus vai tentar convencê-la, à força de uma série de argumentos, a libertá-lo da clausura do Presépio familiar. Seu intento é atingido, a menina o liberta afinal, e aí se tem então apresentada a "verdadeira" versão da fuga do menino Jesus antes de ir ter com o poeta Caeiro. "Perdido" o menino, como a familia vai acabar acreditando, ele é fácil e rapidamente substituído por uma estatuinha de gesso, comprada a tempo.

Mas o diálogo entre a menina-narradora e o menino Jesus é rico de recursos e algumas passagens suas merecem atenção. $O$ menino revela-se preso entre dois destinos cruéis e funestos: "ou ficar para sempre paralisado numa cãibra sagrada na estreiteza deste bercinho, bajulado por uma bonecrada que finge de rústica para iludir o meu amor pela natureza"; ou então "deitar corpo para me prestar à tragédia de uma perpétua agonia que eles veneram, muito contentes de eu pagar na cruz suas ruindades".

Entre sarcástico, irônico, azedo e revoltado, o menino vai revelando as hipocrisias da religião, a passividade dos fiéis, a farsa que envolve os rituais. Faz considerações heterodoxas. De Pilatos diz, por exemplo, tratar-se de "um digníssimo estóico difamado pelos ratos de sacristia". Como no texto de Caeiro, refere-se ao Espírito Santo em termos pouco respeitosos: "Fez-me e bateu as asas. Deve ser por isso que dizem que ele é uma pomba." Diferentemente, mas não sem ironia, refere-se à Nossa Senhora nos seguintes termos: "Uma explorada. Há sindicatos para tudo, menos para esses santos trabalhos." Referindo-se à sua triste situação diz, com visíveis ecos de paganismo: "- É o fado dos deuses." E logo a seguir, afirmando não terem seus seguidores compreendido a essência da sua doutrina, é com as palavras de Aurobindo (as mesmas da epígrafe) que ele vai definir-se: "Ora, o que eu lhes quis demonstrar é que um deus é uma criança eterna, jogando um jogo eterno num eterno jardim. Como é que eu posso ser um deus se eles não me deixam brincar."

Da mesma forma que faz com a religião, ataca a hipocrisia da familia burguesa. É a uma menina estupefata e em eminência constante de choro que ele vai revelando os podres familiares. Tia Micaela é uma bêbada, que "tem razão para se emborrachar pois é feia como os trovões e nunca arranjou homem para apagar o incêndio da sua lubricidade". $O$ "papá" ministra lentas e fatais doses de estricnina ao avô, fazendo-o acreditar tratar-se de poderoso afrodisíaco. Quer ficar logo com a herança e fugir com uma "seresma de pancada alta que só vai com vison e Alfa Romeo". O avô, por sua vez, acreditando nos efeitos da "mezinha", "anda por aí desarvorado a apalpar o rabo às criadas". Trancado 
no armário ao longo de quase todo o ano, o menino sabe do veneno e do álcool ali escondidos, símbolos explícitos da corrupçāo familiar.

E diante da força de tais revelaçōes a menina cede e resolve pôr o pobre menino Jesus em liberdade: "Esta lógica animou-me a empreender a empolgante aventura de libertar um deus prisioneiro." E conclui: "Gesta ímpar, ao que me conste, que jamais ilustrou mesmo as mais fabulosas proezas infantis; porque nas dos adultos tal rasgo nem sequer é de vislumbrar em indivíduos que só inventam deuses para os libertarem das suas aflições."

As falas do menino Jesus não são nada compativeis com a imagem tradicional que se tem do menino no Presépio. Mostram-se extremamente corrosivas, irônicas, sarcásticas, plenas de angústia e desespero também. Contrastam com o que seria de se esperar por parte de um Deus salvador. Lembremos que estas falas, no que concerne ao sarcasmo e à ironia, estão muito próximas das falas do menino no texto de Caeiro, sobretudo na referência depreciativa à Sagrada Familia, à Santíssima Trindade e aos dogmas do Cristianismo. Há um visível descompasso, uma visível tensão entre a imagem pueril do menino e o conteúdo dos seus enunciados. Essa tensão reverbera uma outra, a que parece existir entre os elementos de fantasia, poesia, encantamento e os elementos de aguda crítica de valores presentes em ambos os textos.

E para terminar, creio ser bom cotejar em termos conclusivos os textos de Natália e Caeiro, depois de rastreados já uma série de pontos de contato e de afastamento:

O menino Jesus de Alberto Caeiro foge do céu para vir morar junto com o poeta em meio à natureza. Ele é o Deus que se fez menino e resolveu permanecer menino. Nos termos do poeta: "Ele é o humano que é natural, I Ele é divino que sorri e brinca." Ele é ainda o mestre que ensinou o poeta a olhar para as coisas de modo essencial. Ele é esse próprio modo de olhar, um olhar que se quer inocente e primordial, anterior ao pensamento e às suas ilusões.

O menino Jesus da narradora de Natália Correia é um Deus encarcerado no fundo do armário da familia, onde habita junto com garrafas de bebida e a estricnina. É um menino conhecedor do bafio que emana do interior familiar e, por conseqüência e extensão, da hipocrisia humana de um modo geral. A inocência possível do seu olhar é a de quem vê e não se conforma. É a de quem quer morrer de tanta angústia diante do que vê e do que está condenado a ver. Ele também é, a seu modo, um mestre, pois revela à menina inocente uma série de "verdades". É com lágrimas nos olhos e susto que ela vai sabendo das coisas do mundo. Ao final da narrativa, após a aprendizagem, ela é levada a agir positivamente. Ela liberta o que estava preso - deixa entrar um pouco de ar no armário. Mas ao mesmo tempo ela retém esse menino Jesus na sua memória 
poética como uma imagem preservada da comupção geral do meio familiar e do mundo e como um modo possível e renovado de configurar o divino.

Fernando Pessoa (heteronimicamente Alberto Caeiro) ressurge no texto de Natália Correia em parte fiel a ele mesmo, em parte outro. Essa tensão entre fidelidade e traição, entre recorrência e renovação, harmonia e dissonância em relação ao ponto textual de partida parece marcar as revisitações ao mestre modernista feitas pelos ficcionistas lusos recentes. Um modo polêmico e produtivo de manter o diálogo com a tradição.

\section{RESUMO}

Análise do conto "Onde está o menino Jesus?", de Natália Correia, a partir do seu diálogo com a poesia de Alberto Caciro, heterônimo de Fernando Pessoa. A retomada do universo ficcional pessoano tem se revelado um procedimento produtivo na narrativa portuguesa recente.

Palavras-chave: Narrativa Portugucsa Contemporânea, Intertextualidade, Natália Correia.

\section{ZUSAMMENFASSUNG}

Analyse der Erzählung "Onde está o menino Jesus", von Natália Correia, ab ihrem Dialog mit den Dichtungen von Alberto Caeiro, Heteronym von Fernando Pessoa. Die Wiederaufnahme des fiktionalen Universums von Pessoa hat sich als ein produktives Vorgehen in der neueren portugiesischen Erzählkunst erwiesen.

\section{REFERÊNCIAS BIBLIOGRÁFICAS}

CORREIA, Natália. "Onde está o menino Jesus?". In: TORRES, Alexandre Pinheiro et al. Contos. Lisboa : Editorial Caminho, 1985.

PESSOA, Fernando. O eu profundo e outros elus. 12.ed. Rio de Janeiro: Nova Fronteira, 1980.

SABINO, Amadeu Lopes. $O$ retrato de Rubens. Lisboa : Dom Quixote, 1985.

SARAMAGO, José. O ano da morte de Ricardo Reis. 2.reimp. São Paulo : Companhia das Letras, 1993. 